\title{
Analisis pemahaman siswa SMA kelas XI materi program linear berdasarkan teori apos ditinjau dari gaya belajar
}

\author{
Tina Mayasari, Slamet* \\ Universitas Negeri Malang, Jl. Semarang No. 5 Malang, Jawa Timur, Indonesia \\ *Penulis korespondensi, Surel: slamet.fmipa@um.ac.id
}

Paper received: 01-11-2021; revised: 15-11-2021; accepted: 30-11-2021

\begin{abstract}
The purpose of this study is to describe the understanding of high school students in class XI linear program material based on APOS theory in terms of learning styles. The researcher chose six subjects consisting of two subjects for each learning style. The results of this study indicate the visual group reaches the highest percentage in the stages of action and objects. At the process stage the auditory group is able to reach the highest percentage. As for the stages of the scheme, almost all subjects of the three learning styles are unable to surpass it well.
\end{abstract}

Keywords: APOS theory; learning styles; linear programs.

\begin{abstract}
Abstrak
Tujuan penelitian ini adalah untuk mendeskripsikan pemahaman siswa SMA kelas XI materi program linear berdasarkan teori APOS ditinjau dari gaya belajar. Peneliti memilih enam subjek yang terdiri dari dua subjek untuk masing-masing gaya belajar. Hasil penelitian ini menunjukkan kelompok visual mencapai presentase tertinggi pada tahapan aksi dan objek. Pada tahapan proses kelompok auditori mampu mencapai presentase tertinggi. Sedangkan untuk tahapan skema, hampir semua subjek dari ketiga gaya belajar tidak mampu melampauinya dengan baik.
\end{abstract}

Kata kunci: tahapan APOS; gaya belajar; program linear

\section{Pendahuluan}

Matematika merupakan salah satu mata pelajaran wajib yang harus diberikan kepada siswa, mulai dari tingkat sekolah dasar hingga sekolah menengah atas. Hal ini selaras dengan isi Undang-Undang Nomor 20 Tahun 2003 mengenai Sistem Pendidikan Nasional Pasal 37 Ayat 1 yang menyatakan bahwa, kurikulum pendidikan dasar hingga menengah wajib memuat pendidikan agama, pendidikan kewarganegaraan, bahasa, matematika, ilmu pengetahuan alam, ilmu pengetahuan sosial, seni budaya, pendidikan jasmani dan olahraga, keterampilan/ kejuruan, dan muatan lokal. Menurut Harahap dan Syarifah (2015) alasan matematika dianggap sebagai mata pelajaran yang penting yaitu dengan belajar matematika maka kemampuan kognisi anak akan berkembang.

Menurut Hiebert dan Carpenter (1992) aspek dasar dalam belajar matematika adalah pemahaman, dan setiap pembelajaran matematika seharusnya difokuskan pada penanaman konsep yang berdasarkan pemahaman. Pemahaman konsep pada matematika perlu ditanamkan sejak siswa menerima materi matematika pada tingkat pendidikan dasar. Hal ini diperlukan, karena materi dalam matematika terdapat konsep prasyarat sebagai dasar untuk memahami konsep selanjutnya. Sehingga kemampuan memahami konsep pada materi paling dasar sangat diperlukan, mengingat materi dalam matematika bersifat saling berkesinambungan.

Hasil konstruksi atau rekonstruksi terhadap objek-objek matematika dapat memunculkan sebuah pemahaman terhadap suatu konsep matematika (Dubinsky, 2000). 
Pernyataan ini memberikan ide kepada peneliti untuk mengetahui proses konstruksi siswa. Melalui pemahaman terhadap proses konstruksi, akan membantu siswa untuk mampu mengkonstruk pemahaman matematika dengan baik. Dalam memecahkan suatu permasalahan terdapat proses konstruksi atau rekonstruksi melalui aktivitas berupa aksiaksi matematika, proses-proses, objek-objek yang ketiganya dipadukan dalam suatu skema (Dubinsky, 2000).

Salah satu cara yang dapat digunakan untuk mengetahui tahapan-tahapan yang harus dilalui individu untuk mengkonstruk pemahaman adalah dengan menggunakan teori APOS. APOS merupakan singkatan dari kata aksi, proses, objek, dan skema. Teori APOS memiliki suatu dasar teori yang berpandangan bahwa pengetahuan dan pemahaman matematika seseorang menentukan bagaimana seseorang menanggapi suatu masalah matematika dan menerapkannya pada konteks sosial (Darmawan dan Wahyudin, 2018). Melalui pandangan di atas, dalam menyelesaikan soal matematika siswa memerlukan dua hal yang harus dimiliki yaitu paham mengenai konsep dan mampu menerapkannya ketika konsep itu diperlukan. Penekanan utama dalam teori APOS ini adalah bagaimana siswa mampu melakukan konstruksi mental. Maksud dari konstruksi mental di sini adalah terbentuknya aksi (action), yang direnungkan (interiorized) menjadi proses (process), selanjutnya dirangkum (encapsulated) menjadi objek (object), objek dapat diurai kembali (de-encapsulated) menjadi proses. Kemudian aksi, proses, dan objek diorganisasikan menjadi suatu skema (schema).

Asiala dkk (1997) mendeskripsikan tahapan APOS sebagai berikut: (1) aksi adalah transformasi objek-objek matematika yang dirasakan individu sebagai sesuatu yang harus dilakukan, dan mencoba memahami instruksi setiap tahapan cara melakukan operasi. (2) proses adalah suatu konstruksi mental yang terjadi secara internal yang diperoleh ketika individu telah hafal melakukan transformasi karena sudah biasa melakukan kegiatan pada tahapan aksi secara berulang kali. Konstruksi mental tingkat proses adalah saat individu tidak terlalu banyak memerlukan stimulus dari luar hal ini terjadi karena konsep tertentu sudah berada dalam ingatannya. Pada tingkat ini dia dapat menelusuri kebalikan dan mengomposisikan dengan proses lainnya. (3) Objek dikonstruksi dari proses ketika individu telah mengetahui bahwa proses sebagai suatu totalitas dan menyadari bahwa transformasi dapat dilakukan pada proses tersebut. (4) skema untuk suatu konsep matematika tertentu adalah kumpulan aksi, proses, dan objek atau skema yang dihubungkan oleh beberapa prinsip secara umum.

Program linear merupakan salah satu materi yang masih dianggap sulit oleh siswa. Kurnia (2014) menyatakan bahwa siswa sering melakukan kesalahan dalam memahami soal, kesalahan dalam membuat model matematika, kesalahan dalam melakukan perhitungan, dan kesalahan dalam menarik kesimpulan. Hal ini menunjukkan bahwa siswa mengalami kesulitan dalam mengerjakan. Selain itu, berdasarkan hasil wawancara yang dilakukan peneliti kepada guru matematika SMAN 1 Trenggalek menyatakan bahwa program linear merupakan salah satu materi yang dianggap sulit oleh siswa. Hal ini dibuktikan oleh hasil yang belum maksimal saat dilaksanakan ulangan harian.

Dalam menyelesaikan suatu soal, proses pengerjaan yang dilakukan siswa kemungkinan besar berbeda antar siswa yang satu dengan siswa yang lainnya. Menurut Sari (2013) salah satu aspek yang mempengaruhi proses dalam siswa mengerjakan soal adalah gaya belajar. Dengan gaya belajar yang berbeda, maka proses mengkonstruk pemahaman 
siswa juga berbeda. Karena setiap individu memiliki gaya belajar yang berbeda, maka analisis teori APOS terhadap pemahaman siswa akan memberikan deskripsi yang beragam. Ada tiga macam gaya belajar (berdasarkan modalitas belajar) menurut Depoter dan Hernacki (2008), yaitu: visual, auditori, dan kinestetik. Karena gaya belajar mampu mempengaruhi hasil belajar siswa, maka guru perlu mengetahui gaya belajar yang dimiliki oleh siswa.

Penelitian ini bertujuan untuk mendeskripsikan pemahaman siswa SMA Kelas XI pada materi program linear berdasarkan teori APOS ditinjau dari gaya belajar visual, audio, dan kinestetik.

\section{Metode}

Penelitian ini merupakan penelitian deskriptif kualitatif. Penelitian ini dilaksanakan pada siswa SMA kelas XI, yaitu siswa dari SMAN 1 Trenggalek. Subjek dalam penelitian ini terdiri dari enam siswa, yaitu dua dari siswa kelompok gaya belajar dominan visual, dua siswa kelompok gaya belajar dominan auditori, dan dua dari kelompok gaya belajar dominan kinestetik. Subjek dipilih berdasarkan hasil pengisian angket gaya belajar dan yang memiliki kemampuan komunikasi yang baik.

Peneliti pada awalnya memberikan angket gaya belajar pada siswa kelas XI MIA 3. Selanjutnya dari hasil pengisian angket dilakukan penggolongan gaya belajar, yaitu visual, auditori, atau kinestetik berdasarkan rubrik penilaian angket gaya belajar. Sesuai dengan hasil pengisian angket, peneliti mengambil beberapa kandidat subjek, yaitu dengan kriteria yang memiliki gaya belajar dominan terhadap salah satu jenis gaya belajar. Selanjutnya kandidat tersebut diajukan kepada guru matematika untuk mendapatkan rekomendasi siswa yang memiliki kemampuan komunikasi yang baik. Selanjutnya siswa yang direkomendasikan oleh guru diambil dua dengan gaya belajar dominan visual, dua dominan auditori, dan dua dominan kinestetik. Setelah itu, peneliti memberikan tes tertulis kepada subjek terpilih yaitu dengan materi program linear. Setelah subjek selesai mengerjakan tes tertulis, peneliti melakukan analisis terhadap pekerjaan siswa berdasarkan teori APOS secara garis besar sebelum melakukan wawancara. Lalu peneliti melakukan wawancara kepada setiap subjek penelitian dan merekamnya dengan audio recorder. Selanjunya peneliti mengumpulkan semua informasi tersebut untuk dijadikan data penelitian, mengolahnya, dan merangkumnya untuk diambil suatu kesimpulan sehingga tercapai tujuan penelitian.

\section{Hasil dan Pembahasan}

\subsection{Hasil}

Rata-rata kemampuan pemahaman pada tahapan aksi dari siswa bergaya belajar dominan visual yaitu S1 dan S2 pada soal nomor satu mencapai 75\%. Sedangkan pada soal nomor dua mencapai 62,5\%. Sebenarnya S1 dan S2 ini sudah mampu menuliskan apa yang diperlukan pada tahapan aksi, namun kurangnya pemahaman konsep pada hal-hal umum yang tidak mendapat perbaikan dari guru menyebabkan ketidaksempurnaan S1 dan S2 dalam tahapan aksi. Rata-rata kemampuan pemahaman pada tahapan proses dari siswa bergaya belajar dominan visual yaitu S1 dan S2 baik pada nomor satu maupun nomor dua mencapai presentase 87,5\%. Dalam hal ini, siswa yang berada pada kelompok bergaya belajar visual sudah mampu menginteriorisasikan dari tahapan aksi ke tahapan proses. Presentase ratarata antara S1 dan S2 pada soal nomor satu mencapai 87,5\% dan pada soal nomor dua mencapai $100 \%$. Presentase yang dicapai pada tahapan objek oleh subjek bergaya belajar visual ini tergolong tinggi. Hal ini mengindikasikan bahwa siswa yang mampu mencapai 
tahapan objek dengan baik maka siswa tersebut telah memiliki pengetahuan secara konseptual mengenai materi program linear dan materi yang terkait dengan program linear. Sedangkan presentase rata-rata antara S1 dan S2 pada soal nomor satu pada tahapan skema mencapai 50\% sedangkan pada nomor dua hanya mencapai $25 \%$. Maka dalam hal ini S1 dan S2 belum mampu memadukan aksi, proses, dan objek dengan baik.

Rata-rata kemampuan pemahaman pada tahapan aksi dari siswa bergaya belajar dominan auditori yaitu S3 dan S4 pada soal nomor satu mencapai 50\%. Sedangkan pada soal nomor dua mencapai 37,5\%. Pencapaian presentase kedua subjek bisa dibilang masih rendah. Aktivitas prosedural secara umum yang seharusnya sudah dikuasai namun ternyata masih belum. Rata-rata presentase pencapaian tahapan proses pada siswa bergaya belajar dominan auditori, pada nomor satu S3 dan S4 mencapai 100\%. Dalam hal ini, siswa yang berada pada kelompok bergaya belajar auditori sudah mampu menginteriorisasikan dari tahapan aksi ke tahapan proses. Rata-rata presentase antara S3 dan S4 pada tahapan objek dalam mengerjakan nomor satu yaitu mencapai $75 \%$ sedangkan nomor dua mencapai $50 \%$. Dalam hal ini presentase yang diperoleh tergolong sedang. Namun lebih rendah jika dibandingkan dengan subjek pada gaya belajar visual. Sedangkan presentase rata-rata tahap skema antara S3 dan S4 pada soal nomor satu mampu mencapai presentase 25\% sedangkan pada nomor dua hanya mencapai presentase 25\%. Maka dalam hal ini S3 dan S4 belum mampu memadukan aksi, proses, dan objek dengan baik.

Rata-rata kemampuan pemahaman pada tahapan aksi dari siswa bergaya belajar dominan kinestetik yaitu S5 dan S6 pada soal nomor satu dan nomor dua mencapai 37,5\%. Pencapaian presentase kedua subjek bisa dibilang masih rendah. Aktivitas prosedural secara umum yang seharusnya sudah dikuasai namun ternyata masih belum. Jika dicari perbandingan presentase tahapan proses antara S5 dan S6 pada pengerjaan soal nomor satu $50 \%$, sedangkan pada nomor dua hanya mencapai $25 \%$. Dalam hal ini, siswa yang berada pada kelompok bergaya belajar kinestetik belum mampu menginteriorisasikan dari tahapan aksi ke tahapan proses. Rata-rata antara S5 dan S6 pada tahapan objek ini ketika mengerjakan soal tahapan objek, baik nomor satu maupun nomor dua hanya mencapai $25 \%$. Hal ini mengindikasikan bahwa S5 dan S6 belum mampu mencapai tahapan objek dengan baik sehingga siswa tersebut belum memiliki pengetahuan secara konseptual mengenai materi program linear dan materi yang terkait dengan program linear. Rata-rata presentase antara S5 dan S6 pada tahapan skema untuk soal nomor satu mampu mencapai presentase $50 \%$ sedangkan pada nomor dua hanya mencapai presentase 25\%. Maka dalam hal ini S5 dan S6 belum mampu memadukan aksi, proses, dan objek dengan baik.

\subsection{Pembahasan}

Dalam tahapan aksi subjek yang memiliki gaya belajar visual, auditori, dan kinestetik terdapat beberapa kesamaan yaitu sudah membuat permisalan, namun belum tepat. Permisalan yang dibuat tidak sesuai dengan apa yang akan dicari. Semua subjek dari ketiga gaya belajar memisalkan jenis item, bukan banyaknya item dari setiap jenisnya. Selain itu, subjek dari ketiga gaya belajar jarang yang mencantumkan fungsi non negatif. Subjek pada gaya belajar visual dan kinestetik melakukan kesalahan penulisan simbol pada fungsi objektif. Namun, semua subjek dari ketiga jenis gaya belajar sudah mampu menuliskan fungsi kendala dengan benar. Dari sini dapat dilihat bahwa pada tahapan aksi subjek hanya melakukan kegiatan prosedural. Hal ini sesuai dengan pendapat Zazkis \& Campbell (1996) 
yang menyatakan bahwa pemahaman siswa menurut teori APOS pada tahapan aksi, maka siswa tersebut hanya melakukan kegiatan prosedural.

Dalam tahapan proses subjek yang memiliki gaya belajar visual, auditori, dan kinestetik terdapat beberapa hal yang dapat dibandingkan, yaitu mampu mencari titik potong dengan sumbu koordinat, namun subjek dari gaya belajar kinestetik belum menjelaskannya dengan lengkap. Begitu pula dalam hal uji titik $(0,0)$ sebagai langkah mencari daerah selesaian, subjek dengan gaya belajar visual dan auditori sudah mampu menjelaskannya dengan lengkap sedangkan subjek dari gaya belajar kinestetik masih belum lengkap. Semua subjek dari ketiga jenis gaya belajar mampu menggambar grafik dan menentukan daerah selesaian dengan benar. Hal ini sesuai dengan pernyataan Widada (dalam Hanifah, 2016) yaitu bila aksi dilakukan secara berulang kali dan dilakukan refleksi, maka aksi-aksi tersebut diinteriorisasikan ke dalam proses.

Dalam tahapan objek subjek yang memiliki gaya belajar visual, auditori, dan kinestetik semua subjek dari ketiga jenis gaya belajar sudah mampu mencari titik potong antar grafik dan mampu mensubstitusikan titik maksimum ke fungsi objektif dan diperoleh hasil yang benar. Keadaan ini sesuai dengan pendapat yang dikemukakan oleh Zazkis \& Campbell (1996) yaitu jika pemahaman siswa telah mencapai pada tahapan objek menurut teori APOS, maka dapat dikatakan bahwa siswa tersebut telah memiliki pemahaman konseptual. Namun, pemilik gaya belajar auditori dan kinestetik belum mampu menuliskan proses substitusi dengan benar, sehingga jika dimaknai secara matematis tidak bisa. Untuk subjek dengan gaya belajar kinestetik, keduanya tidak menuliskan cara mencari titik potong antar grafik untuk mencari titik maksimum, baik dalam tes tertulis maupun saat wawancara.

Dalam tahapan skema, subjek yang memiliki gaya belajar visual, auditori, dan kinestetik semuanya belum mampu menuliskan kesimpulan yang benar. Subjek belum mampu menghubungkan hasil akhir yang diperoleh dengan apa yang ditanyakan oleh soal. Begitupula dengan poin kedua, baik subjek dari gaya belajar visual, auditori, maupun kinestetik belum mampu mengungkapkan secara runtut dan lengkap penjelasan setiap tahapannya mulai dari aksi, proses, dan skema baik secara tertulis maupun secara verbal. Di mana skema akan terbentuk jika siswa mampu memadukan aksi, proses, objek, dan mungkin skema lain (Asiala, dkk, 1997).

\section{Simpulan}

\subsection{Simpulan}

Dari analisis hasil penelitian terhadap pemahaman siswa dengan gaya belajar visual, auditori, dan kinestetik terhadap materi program linear berdasarkan pada teori APOS dihasilkan beberapa hal sebagai berikut: (1) Pada pemahaman tahapan aksi kelompok dengan gaya belajar dominan visual lebih banyak melakukan tahapan aksi dari pada kelompok yang lain. Hal ini menunjukkan bahwa siswa dengan gaya belajar visual akan lebih mampu meniru apa yang dicontohkan oleh gurunya dari pada siswa yang memiliki gaya belajar yang lain. (2) Pada pemahaman tahapan proses setiap kelompok menunjukkan kenaikan dari pada tahapan aksi, di mana subjek dengan gaya belajar dominan auditori paling banyak melakukan tahapan proses. Dari sini berarti bahwa subjek dengan gaya belajar auditori mampu menginteriorisasikan aksi ke proses dengan baik. (3) Pada pemahaman tahapan objek kelompok subjek dengan gaya belajar dominan visual melakukan tahapan objek dari pada kelompok lain. Hal ini menunjukkan bahwa kelompok siswa dengan gaya 
belajar dominan visual sudah lebih banyak pemahaman konseptualnya. (4) Pada pemahaman tahapan skema semua kelompok gaya belajar melakukan tahapan skema dengan tingkatan yang sama. Dalam hal ini berarti semua subjek belum mampu melakukan pengintegrasian konsep matematika, yaitu menghubungkan antara satu tahapan dengan tahapan yang lainnya bahkan dengan tahapan skema yang lain.

\subsection{Saran}

Beberapa saran atau rekomendasi yang dapat diajukan dari hasil penelitian ini adalah sebagai berikut: (1) Bagi guru, perlu memperbanyak latihan soal terutama yang melatih siswa agar melakukan tahapan aksi. Terutama untuk anak dengan gaya belajar dominan kinestetik yang cenderung masih sedikit melakukan tahapan aksi. Selain itu, guru harus memberikan penguatan dan pembenahan terhadap konsep-konsep dasar yang sudah dipegang kuat oleh siswa namun masih salah, seperti permisalan dan penulisan simbol matematis. Guru juga harus menekankan pada pembuatan kesimpulan, serta lebih menekankan kepada pemahaman secara konsep tidak hanya prosedural. (2) Bagi calon peneliti selanjutnya, perlu diadakan pretest sebelum melakukan tes tertulis agar kemampuan pemahaman siswa terhadap suatu materi lebih terlihat. Wawancara yang dilakukan juga harus lebih mendetil agar informasi tambahan yang diperoleh lebih banyak dan lebih akurat.

\section{Daftar Rujukan}

Asiala, M., Brown, A., DeVries, D. J., Mathews, D., \& Thomas, K. (1996). A framework for research and curriculum development in undergraduate mathematics education. In Research in collegiate mathematics education.

Darmawan, D. \& Wahyudin, D. (2018). Model pembelajaran di sekolah. Bandung: PT Remaja Rosdakarya

DePorter, B. (2006). Quantum learning: Membiasakan belajar nyaman dan menyenangkan.

Dubinsky, E. (2000). Using a theory of learning in college mathematics courses. Teaching and learning undergraduate mathematics, 12, 10-15.

Hanifah. (2016). Model APOS inovasi pada pembelajaran matematika. Bengkulu: Unit Penerbitan FKIP Universitas Bengkulu

Harahap, D. H., \& Syarifah, R. (2017). Studi kasus kesulitan belajar matematika pada remaja. Jurnal Psikologi, 11(1).

Hiebert, J., \& Carpenter, T. P. (1992). Handbook of research on mathematics teaching and learning. Learning and teaching with understanding, 65-97.

Kurnia, D. (2014). Analisis Kesalahan Siswa dalam Menyelesaikan Soal Cerita pada Pembelajaran Matematika. Jurnal Pendidikan Matematika Unila, Vol 2, No. 1.

Sari, N. P. (2013). Pengaruh gaya belajar siswa terhadap prestasi belajar matematika siswa. EMPATHY Jurnal Fakultas Psikologi, 2(1).

Zazkis, R., \& Campbell, S. (1996). Divisibility and multiplicative structure of natural numbers: Preservice teachers' understanding. Journal for Research in Mathematics Education, 27(5), 540-563. 